International Journal of STEM Education for Sustainability, Vol 2, No.1, 2022, pp. 105-132

e-ISSN 2798-5091. DOI. 10.53889/ijses.v2i1.15

\title{
High School Students' Motivation Towards Physics Learning During Covid-19 Outbreak
}

\author{
Submitted 1 July 2021 Revised 25 July 2021 Accepted 25 July 2021 \\ Sukmawati Sukmawati ${ }^{1}$, Riskan Qadar $^{2 *}$, Nurul Fitriah Sulaeman ${ }^{3}$ \\ ${ }^{1,2,3}$ Department of Physics Education, Faculty of Teacher Training and Education, \\ Universitas Mulawarman, Samarinda, Indonesia \\ Corresponding Email: *riskanqadar@fkip.unmul.ac.id
}

\begin{abstract}
Learning activities during the covid-19 pandemic have adapted by utilizing e-learning platforms, and this condition encourages the need to help students, especially by knowing their many motivations. Thus, this study aims, 1) To determine the level of student learning motivation in general and by gender 2) To determine the percentage of the ARCS aspect of each school on the level of learning motivation in general and by gender, 3) To determine the percentage of the ARCS aspect as a whole to the level of motivation to learn in general and by gender after participating in Physics learning boldly. The research sample was 275 students of class X MIPA from 8 public schools in Balikpapan. Data collection using questionnaires and interview techniques. The results showed that the general level of motivation was moderate with a percentage of $49 \%$, while the value based on the proportion of gender for male students was $37 \%$ and the percentage for students was $63 \%$. , $64.23 \%$ for Relevance, $68.19 \%$ for Confidence, and $71.95 \%$ for Satisfaction, while the proportion value based on gender in Attention is $67.53 \%$ for male, $67.80 \%$ for female; Male relevance $65.07 \%$, female $63.78 \%$; Confidence of men $69.41 \%$, women $67.55 \%$; and male satisfaction $72.37 \%$, female $71.74 \%$. Basically, this study aims to determine the level of motivation to learn physics and the aspects that affect that motivation; the higher the motivation, the greater the learning success. This study shows that high school students' motivation to learn physics based on the ARCS learning model is in the medium category. By knowing the level of learning motivation from several aspects that have been explored, we can increase students' motivation to learn to the maximum in the next lesson.
\end{abstract}

Keywords: Motivation, E-Learning, ARCS

\section{INTRODUCTION}

The temporary closure of educational institutions as an effort to contain the spread of the COVID-19 pandemic worldwide impacts millions of students (Aji, 2020). During the current pandemic, online learning plays an essential role in the continuity of the teaching and learning process. We know that almost all learning process activities routinely carried out in schools directly (face to face) are now carried out online (remotely). Online learning cannot be separated from the influence of technological developments. The need for technology-based teaching and learning concepts and mechanisms is inevitable. According to Nasution (2018), technological literacy is also defined as an ability consisting of scientific aspects, critical thinking skills, and decision making to utilize technology/innovation of human work effectively, especially in education.

Herniati et al (2017) argues that the low student learning outcomes are caused by several things, including the ongoing physics learning that does not involve students in learning, in 
other words, teacher-centered learning. With the application of online learning methods where students dominate the learning process, so that knowledge can be found, formed, and developed by students, while the teacher only acts as a mediator or facilitator to form and develop knowledge itself, not to transfer knowledge. The results in research conducted by Dewi (2020) show that the impact of COVID-19 on the implementation of online learning in schools can be carried out quite well if there is a collaboration between teachers, students, and parents in studying at home.

Apart from the online learning process as the use of information technology during a pandemic, supporters of the procurement of science and technology are an important indicator in improving the quality of education in the current era of industrial revolution 4.0. Quality education depends on how students experience the learning process. According to Ulfah et al (2015), motivation is needed to encourage students to learn something in the learning process. A student who is motivated to learn something will try to learn it well and diligently to get good results. Conversely, students who lack or do not have the motivation to learn, then these students will be easily tempted to do other things instead of learning. This means that a person's motivation to learn is very influential on his perseverance and success in learning.

Suprijono (2010) stated that motivation strategies can be developed based on the ARCS model proposed by Keller. This theory is a motivational condition consisting of four variables. Keller (1983) classifies learning motivation into four variables, namely: (1) attention, (2) relevance, (3) confidence, and (4) satisfaction. In order to find out how much students' learning motivation can be seen from how far students' attention is in learning, how far students feel there is a connection or relevance of learning content to their needs, how far students feel confident in their ability to do the tasks given, and how far students feel satisfied with the learning activities that have been carried out. This motivation theory was eventually developed to encourage the emergence of motivation in students through the ARCS motivation theory (Jamil, 2019).

Motivation is influenced by many factors, one of which is gender. Gender is also a characteristic that distinguishes students in learning and processing information. According to Nur \& Palobo (2018), gender is a psychosocial aspect that determines how a person acts and behaves in order to be accepted in his social environment. Gender differences can differentiate a person's thinking and determine the solution to the problem taken. According to Anita (2015), gender factor or gender is one of the motivational factors that arise in students and affect the learning process. There are differences in achievement where students' amount of motivation 
manifests achievement itself. This study aims to determine the differences in learning motivation based on gender.

\section{METHOD}

\section{Participant Context}

The participants in this study were 279 high school students in Balikpapan, Indonesia

\section{Data Collection}

The type of research used in this research is descriptive quantitative research, with the sampling technique in this study determined through the Cluster Sampling (Area Sampling) technique. This research was carried out in December 2020, the research subject consists of students of class $\mathrm{X}$ from 8 high schools in mathematics and natural sciences program in Balikpapan, Indonesia that can be observed in Table 1 and Table 2.

Table 1. The number of participants

\begin{tabular}{ccc}
\hline No. & Schools & Total of Participant \\
\hline 1. & SHS - A & 37 Students \\
2. & SHS - B & 70 Students \\
3. & SHS - C & 33 Students \\
4. & SHS - D & 28 Students \\
5. & SHS - E & 35 Students \\
6. & SHS - F & 14 Students \\
7. & SHS - G & 23 Students \\
8. & SHS - H & 35 Students \\
\hline & Total & 275 Students \\
\hline
\end{tabular}

Table 2. Number of Participants based on Gender

\begin{tabular}{cccc}
\hline \multirow{2}{*}{ No. } & \multirow{2}{*}{ Schools } & \multicolumn{2}{c}{ Total of Participants based on Gender } \\
\cline { 3 - 4 } & & Boys & Girls \\
\hline 1. & SHS - A & 10 & 27 \\
2. & SHS - B & 27 & 43 \\
3. & SHS - C & 14 & 19 \\
4. & SHS - D & 9 & 20 \\
5. & SHS - E & 11 & 24 \\
6. & SHS - F & 3 & 11 \\
7. & SHS - G & 10 & 13 \\
8. & SHS - H & 14 & 21 \\
\hline \multicolumn{2}{c}{ Total of students } & 95 & 180 \\
\hline
\end{tabular}

The sample used to measure the level of learning motivation in the study was 275 students, including 95 male students and 180 female students.

We were collecting data in this study using a questionnaire and interview techniques. A questionnaire technique was used to determine the percentage of each student's level of motivation to learn physics. The interview technique was used as supporting data through the results of statements obtained from interviews by several students. 
The assessment instruments are in the form of questionnaires and interview sheets. The measurement of learning motivation is based on the aspect of learning motivation developed by Keller in 1983, where this aspect consists of attention, relevance, confidence, and satisfaction, which is then developed into several indicators, which can be observed in Table 3.

Table 3. Aspects and Indicators of Learning Motivation

\begin{tabular}{ll}
\hline Aspects & \multicolumn{1}{c}{ Indicators } \\
\hline \multirow{2}{*}{ Attention } & a. Attention to the learning process \\
& b. The willingness of students to reach and find information related to physics \\
& material on the learning process \\
Relevance & a. Able to relate concepts from material \\
& b. Mention the application of physics concepts in everyday life, and be able \\
Confidence & a. Dare to express opinions or answer questions \\
& b. Solve problems related to physics material independently \\
Satisfaction & a. Trying to be active in physics learning activities \\
& b. Complete project assignments, practice questions, and physics exam \\
& questions
\end{tabular}

Source: Sari (2017)

To see the level of student learning motivation online, it is done by analyzing the results obtained. This questionnaire/questionnaire is made with a closed model, where students choose their own answers that have been provided. There are four alternative answer choices. The measurement is expressed in a score where each statement is given four answer choice criteria, and each answer choice is given a score between 1 and 4 . The score of each answer criterion is for positive (+) and negative (-) statements. The alternative scores for the answer choices are presented in Table 4.

Table 4 Alternative Answer Choice Scores for Learning Motivation Questionnaire

\begin{tabular}{ccc}
\hline \multirow{2}{*}{ Alternative Answer } & \multicolumn{2}{c}{ Score of Alternative Answer } \\
\cline { 2 - 3 } & Positive & Negative \\
\hline Very agree & 4 & 1 \\
Agree & 3 & 2 \\
Disagree & 2 & 3 \\
Very disagree & 1 & 4 \\
\hline
\end{tabular}

Source: Fitriah (2018)

Questionnaires will be distributed to students in the form of links assisted by Google Forms to make it easier for students to complete motivational questionnaires.

\section{Data analysis technique}

Data analysis techniques to determine the classification of motivation to learn physics through a questionnaire are done by accumulating the scores of all questionnaire items from all research samples. The score is then processed to find the average score for learning motivation and the interval value, which will later be used as a benchmark in categorizing students' learning 
motivation.

The learning motivation questionnaire consists of 32 statements and has a maximum score of 4 , so the calculation to determine the class limit of each questionnaire is as follows:

Maximal score: 4 x $32=128$

Minimal score: 1 x $32=32$

Range: $128-32=96$

The length of the interval class is

$P=\frac{\text { Range }}{\text { Interval }}=\frac{96}{5}=19$

So, the length of the interval class is 19

The classification criteria for measuring learning motivation are presented in Table 5.

Table 5 Classification of Learning Motivation Measurement

\begin{tabular}{cc}
\hline Interval & Classification \\
\hline $108-128$ & Very high \\
$89-107$ & High \\
$70-88$ & Medium \\
$51-69$ & Low \\
$32-50$ & Very low \\
\hline
\end{tabular}

Source: Fitriah (2018)

The next step is to determine the percentage (\%) of each classification of learning motivation. How to determine the percentage of each classification of motivation to learn Physics is as follows.

$\mathrm{K}=\frac{P}{Q} \times 100 \%$

Source: Sari (2018)

Information:

$\mathrm{K}=$ Percentage value Classification of learning motivation

$P=$ Actual score

$\mathrm{Q}=$ Ideal score

The results of the questionnaire analysis were used to determine the level of students' learning motivation during physics learning which was expressed as a percentage of each category of very high, high, medium, low, and very low motivation in general and by gender. Furthermore, the percentage of each ARCS aspect is calculated for the motivation to learn 
Physics. Calculating the percentage of each ARCS aspect of the student learning motivation questionnaire is the same as calculating the motivational classification.

\section{RESULTS AND DISCUSSION}

\section{SHS-A}

Based on the assessment of learning motivation in SHS-A schools during online learning, it is in the Medium category with an average score of 85 subjects out of a total of 37 subjects, obtaining a subject percentage value of $66.45 \%$. These conditions indicate that students' learning motivation in SHS-A is included in the category of moderate learning motivation

\section{Classification of Overall Student Learning Motivation}

In this section, students' online learning motivation at SHS-A schools will be classified into five categories, including very high, high, medium, low, and very low. This classification aims to determine the value of a group or sample. The results obtained from the classification of online learning motivation in SHS-A schools can be observed in Table 6 .

Table 6 Overall Achievement of Online Learning Motivation Classification Results in SHS-A

\begin{tabular}{ccc}
\hline \multicolumn{3}{c}{ Learning Motivation Classification } \\
\hline Classification & Number of students & Percentage \\
\hline Very high & 2 & $5.40 \%$ \\
High & 15 & $40.54 \%$ \\
Medium & 15 & $40.54 \%$ \\
Low & 3 & $8.10 \%$ \\
Very low & 2 & $5.40 \%$ \\
\hline
\end{tabular}

Based on Table 7, the online learning motivation classification at SHS-A as a whole with the largest number of subjects in the high category and the medium category as many as 15 students with a percentage value of $40.54 \%$

\section{Classification of Student Learning Motivation Based on Gender}

The data obtained from the classification of students' learning motivation based on gender in SHS-A schools can be observed in Table 7

Table 7 Results of Online Learning Motivation Classification in SHS-A Based on Gender

Learning Motivation Classification Based on Gender

\begin{tabular}{ccccc}
\hline \multirow{2}{*}{ Classification } & \multicolumn{2}{c}{ Number of students } & \multicolumn{2}{c}{ Percentage } \\
\cline { 2 - 5 } & Boys & Girls & Boys & Girls \\
\hline Very high & 1 & 1 & $10 \%$ & $3.70 \%$ \\
High & 3 & 12 & $30 \%$ & $44.44 \%$ \\
Medium & 6 & 9 & $60 \%$ & $33.33 \%$ \\
Low & 0 & 3 & 0 & $11.11 \%$
\end{tabular}


Very low 0 2 0 $7.40 \%$

The results of the classification of learning motivation based on gender with the number of male students as many as ten students and the number of female students as many as 27 . Based on the data on learning motivation in SHS-A schools, male students are in the medium category with a percentage value of $60 \%$, while female students are in the middle category. In the high category with a percentage value of $44 \%$. In this case, there are differences in motivational categories between male students and female students, and this difference can be influenced by many factors, both internal and external, from each student.

\section{Assessment Results on the Indicators of Students' Learning Motivation Aspects}

Exploring student motivation in learning can be done in many ways. In this case, the author uses four aspect indicators as an assessment, including attention, relevance, confidence, and satisfaction. From the four indicators of learning motivation, it will be seen which aspect of motivation is more dominantly owned by students while following online learning. The data obtained from the assessment results on the indicators of aspects of student learning motivation can be observed in Table 8 .

Table 8 Data Acquisition Aspects of Learning Motivation in General Aspects of Learning Motivation in General

\begin{tabular}{lcc}
\hline \multicolumn{1}{c}{ Aspects } & Number of students & Percentage \\
\hline Attention & 803 & $25 \%$ \\
Relevance & 783 & $24 \%$ \\
Confidence & 805 & $25 \%$ \\
Satisfaction & 851 & $26 \%$ \\
\hline
\end{tabular}

Based on the results of the acquisition of indicators of learning motivation aspects in general in SHS-A schools in Table 8 the Satisfaction aspect indicator has the largest score of 851 with a percentage of $26 \%$. This shows that students' motivation is quite good in terms of satisfaction in receiving learning. While the Relevance aspect with a score of 783 with a percentage of $24 \%$ is at the lowest score, but is still classified as moderate motivation.

\section{The Result of the Assessment of the Indicators of Students' Learning Motivation Based on Gender}

The data obtained from the assessment results on indicators of student motivation aspects based on gender in SHS-A schools can be observed in Table 9.

Table 9 Data Acquisition Aspects of Learning Motivation Based on Gender

Aspects of Learning Motivation Based on Gender

\begin{tabular}{lcccc}
\hline \multirow{2}{*}{ Aspects } & \multicolumn{2}{c}{ Number of students } & \multicolumn{2}{c}{ Percentage } \\
\cline { 2 - 5 } & Boys & Girls & Boys & Girls \\
\hline Attention & 220 & 583 & $24 \%$ & $25 \%$
\end{tabular}


International Journal of STEM Education for Sustainability, Vol 2, No.1, 2022, pp. 105-132

e-ISSN 2798-5091. DOI. 10.53889/ijses.v2i1.15

\begin{tabular}{lllll} 
Relevance & 215 & 568 & $24 \%$ & $24 \%$ \\
Confidence & 232 & 573 & $25 \%$ & $25 \%$ \\
Satisfaction & 248 & 603 & $27 \%$ & $26 \%$ \\
\hline
\end{tabular}

Based on the results of data acquisition per-indicator aspects of learning motivation based on gender in SHS-A schools, the Satisfaction aspect has the highest percentage value, namely $27 \%$ for male students and $26 \%$ for female students. In this case, there is a $1 \%$ difference between female and male students in SHS-A.

\section{SHS-B}

Based on the results of the assessment of learning motivation in SHS-B schools during online learning, it is in the High category with an average score of 89 subjects out of a total of 70 subjects, the percentage value of subjects is $69.15 \%$. This condition shows that students' learning motivation in SHS-B is included in the category of High learning motivation.

\section{Classification of Overall Student Learning Motivation}

In this section, students' online learning motivation at SHS-B schools will be classified into five categories, including very high, high, medium, low, and very low. This classification aims to determine the value of a group or sample. The results obtained from the classification of online learning motivation in SHS-B schools can be observed in Table 10.

Table 10 Overall Achievement of Online Learning Motivation Classification Results in SHS$\mathrm{B}$

\begin{tabular}{lcc}
\hline \multicolumn{3}{c}{ Learning Motivation Classification } \\
\hline \multicolumn{1}{c}{ Classification } & Number of students & Percentage \\
\hline Very high & 5 & $7.14 \%$ \\
High & 27 & $38.57 \%$ \\
Medium & 36 & $51.43 \%$ \\
Low & 2 & $2.86 \%$ \\
Very low & 0 & 0 \\
\hline
\end{tabular}

Based on Table 10, the results of online learning motivation classification in SHS-B as a whole, with the most significant number of subjects in the medium category, were 36 students with a percentage value of $51.43 \%$.

\section{Classification of Student Learning Motivation by Gender}

The data obtained from the classification of students' learning motivation based on gender in SHS-B schools can be observed in Table 11.

Table 11 Results of Online Learning Motivation Classification in SHS-B Based on Gender Learning Motivation Classification Based on Gender

\begin{tabular}{lcccc}
\hline \multirow{2}{*}{ Classification } & \multicolumn{2}{c}{ Number of students } & \multicolumn{2}{c}{ Percentage } \\
\cline { 2 - 5 } & Boys & Girls & Boys & Girls \\
\hline Very high & 2 & 3 & $8 \%$ & $6.67 \%$ \\
High & 11 & 16 & $44 \%$ & $35.56 \%$ \\
& & & 112 &
\end{tabular}


International Journal of STEM Education for Sustainability, Vol 2, No.1, 2022, pp. 105-132

e-ISSN 2798-5091. DOI. 10.53889/ijses.v2i1.15

\begin{tabular}{lcccc} 
Medium & 12 & 24 & $48 \%$ & $53.33 \%$ \\
Low & 0 & 2 & 0 & $4.44 \%$ \\
Very low & 0 & 0 & $8 \%$ & $6.67 \%$ \\
\hline
\end{tabular}

The classification of learning motivation based on gender with the number of male students is 25 and female students is 45 . Based on the data on the motivation to study at the SHS-B school, male students are in the medium category with a percentage value of $48 \%$, while female students are in the middle category. In the same category with a percentage value of $53 \%$. There are differences in motivational categories between male students and female students in this case. This difference can be influenced by both internal and external factors from each student.

\section{Assessment Results on the Indicators of Students' Learning Motivation Aspects}

Exploring the level of student motivation in learning can be done in many ways. In this case, we used four aspect indicators: attention, relevance, confidence, and satisfaction. From the four indicators of learning motivation, it will be seen which aspect of motivation is more dominantly owned by students while following online learning. The data obtained from the assessment results on indicators of student motivation aspects can be observed in Table 12 .

Table 12 Data Acquisition Aspects of Learning Motivation in General

Aspects of Learning Motivation in General

\begin{tabular}{lcc}
\hline \multicolumn{1}{c}{ Aspects } & Number of students & Percentage \\
\hline Attention & 1563 & $25 \%$ \\
Relevance & 1480 & $24 \%$ \\
Confidence & 1534 & $25 \%$ \\
Satisfaction & 1607 & $26 \%$ \\
\hline
\end{tabular}

Based on the results of the acquisition of indicators of learning motivation aspects in general in SHS-B schools in Table 12, the indicators of Satisfaction aspect have the largest score of 1607 with a percentage of $26 \%$. This shows that students' motivation is quite good in terms of satisfaction in receiving learning. While the Relevance aspect with a score of 71480 and percentage of $24 \%$ is at the lowest score, but is still classified as moderate motivation.

\section{The Result of the Assessment of the Indicators of Students' Learning Motivation Based on Gender}

The data obtained from the assessment results on indicators of student motivation aspects based on gender in SHS-B schools can be observed in Table 13.

Table 13 Data Acquisition of Aspects of Learning Motivation Based on Gender

Aspects of Learning Motivation Based on Gender

\begin{tabular}{|c|c|c|c|c|}
\hline \multirow{2}{*}{ Aspects } & \multicolumn{2}{|c|}{ Number of student } & \multicolumn{2}{|c|}{ Percentage } \\
\hline & Boys & Girls & Boys & Girls \\
\hline Attention & 611 & 952 & $25 \%$ & $25 \%$ \\
\hline
\end{tabular}


International Journal of STEM Education for Sustainability, Vol 2, No.1, 2022, pp. 105-132

e-ISSN 2798-5091. DOI. 10.53889/ijses.v2i1.15

\begin{tabular}{lllll} 
Relevance & 598 & 882 & $25 \%$ & $24 \%$ \\
Confidence & 608 & 926 & $25 \%$ & $25 \%$ \\
Satisfaction & 624 & 983 & $25 \%$ & $26 \%$ \\
\hline
\end{tabular}

Based on the results of data acquisition per-indicator aspects of learning motivation based on gender in SHS-B schools, the Satisfaction aspect has the highest percentage value, namely $25 \%$ for male students and $26 \%$ for female students. In this case, there is a $1 \%$ difference between female and male students in SHS-B.

\section{SHS-C}

Based on the assessment of learning motivation at the SHS-C school during online learning, it is in the Medium category with an average score of 85 subjects from 33 subjects. The percentage score of subjects is $66.67 \%$. These conditions indicate that students' learning motivation in SHS-C is included in the category of moderate learning motivation

\section{Classification of Overall Student Learning Motivation}

In this section, students' online learning motivation at SHS-C schools will be classified into five categories, including very high, high, medium, low, and very low. This classification aims to determine the value of a group or sample. The results obtained from the classification of online learning motivation in SHS-C schools can be observed in Table 14.

Table 14 Results of Online Learning Motivation Classification in SHS-C Overall

Learning Motivation Classification

\begin{tabular}{lcc}
\hline \multicolumn{1}{c}{ Classification } & Number of students & Percentage \\
\hline Very high & 0 & 0 \\
High & 14 & $43.75 \%$ \\
Medium & 15 & $46.87 \%$ \\
Low & 2 & $6.25 \%$ \\
Very low & 1 & $3.12 \%$ \\
\hline
\end{tabular}

Based on Table 14, the Results of Online Learning Motivation Classification in SHS-C Overall with the largest number of subjects were in the high category and the medium category as many as 15 students with a percentage value of $46.87 \%$.

\section{Classification of Student Learning Motivation by Gender}

The data obtained from the classification of students' learning motivation based on gender in SHS-C schools can be observed in Table 15.

Tabel 15 Results of Online Learning Motivation Classification in SHS-C Based on Gender

\begin{tabular}{lcccc}
\hline \multicolumn{4}{c}{ Learning Motivation Classification Based on Gender } \\
\hline \multirow{2}{*}{ Classification } & \multicolumn{3}{c}{ Number of students } & \multicolumn{2}{c}{ Percentage } \\
\cline { 2 - 5 } & Boys & Girls & Boys & Girls \\
\hline Very high & 0 & 0 & 0 & 0 \\
High & 5 & 9 & $35.71 \%$ & $50 \%$ \\
& & & 114 &
\end{tabular}


International Journal of STEM Education for Sustainability, Vol 2, No.1, 2022, pp. 105-132

e-ISSN 2798-5091. DOI. 10.53889/ijses.v2i1.15

\begin{tabular}{llccc} 
Medium & 8 & 7 & $57.14 \%$ & $39 \%$ \\
Low & 0 & 2 & 0 & $11 \%$ \\
Very low & 1 & 0 & $7.14 \%$ & 0 \\
\hline
\end{tabular}

The classification of learning motivation based on gender with the number of male students is eight and female students is 9. Based on the data on motivation to learn in the SHS$\mathrm{C}$ school, male students are in the medium category with a percentage value of $57.14 \%$, while female students are in the middle category. In the high category with a percentage value of $50 \%$. In this case, there are differences in motivational categories between male students and female students, this difference can be influenced by many factors, both internal and external from each student.

\section{Assessment Results on the Indicators of Students' Learning Motivation Aspects}

Exploring the level of student motivation in learning can be done in many ways. In this case, the author uses four aspect indicators: attention, relevance, confidence, and satisfaction. From the four indicators of the aspect of learning motivation, it will be seen which aspect of motivation is more dominantly owned by students while following online learning. The data obtained from the assessment of the indicators of the aspects of student learning motivation can be observed in Table 16.

Tabel 16 Data Acquisition Aspects of Learning Motivation in General Aspects of Learning Motivation in General

\begin{tabular}{lcc}
\hline \multicolumn{1}{c}{ Aspects } & Number of students & Percentage \\
\hline Attention & 673 & $66 \%$ \\
Relevance & 637 & $62 \%$ \\
Confidence & 693 & $68 \%$ \\
Satisfaction & 728 & $71 \%$ \\
\hline
\end{tabular}

Based on the acquisition of indicators of learning motivation aspects in general in SHSC schools in Table 16, the indicators of Satisfaction aspect have the largest score of 728 with a percentage of $71 \%$. This shows that students' motivation is quite good in satisfaction in receiving learning. While the Relevance aspect with a score of 637 with a percentage of $62 \%$ is at the lowest score, it is still classified as moderate motivation.

\section{The Result of the Assessment of the Indicators of Students' Learning Motivation Based on Gender}

The data obtained from the assessment results on indicators of student motivation aspects based on gender in SHS-C schools can be observed in Table 17. 
Tabel 17 Data Acquisition of Aspects of Learning Motivation Based on Gender

Aspects of Learning Motivation Based on Gender

\begin{tabular}{lcccc}
\hline \multirow{2}{*}{ Aspects } & \multicolumn{2}{c}{ Number of students } & \multicolumn{2}{c}{ Percentage } \\
\cline { 2 - 5 } & Boys & Girls & Boys & Girls \\
\hline Attention & 284 & 389 & $25 \%$ & $15 \%$ \\
Relevance & 271 & 366 & $25 \%$ & $24 \%$ \\
Confidence & 295 & 398 & $25 \%$ & $25 \%$ \\
Satisfaction & 311 & 417 & $25 \%$ & $26 \%$ \\
\hline
\end{tabular}

Based on the results of data acquisition per-indicator aspects of learning motivation based on gender in SHS-C schools, the Satisfaction aspect has a percentage value of $25 \%$ for male students and $26 \%$ for female students. In this case, there is a $1 \%$ difference between female and male students in SHS-C.

\section{SHS-D}

Based on the assessment of learning motivation in SHS-D schools during online learning, it is in the Medium category with an average score of 86 subjects out of a total of 29 subjects. The percentage value of subjects is $67.48 \%$. These conditions indicate that students' learning motivation in SHS-D is included in the category of moderate learning motivation.

\section{Classification of Overall Student Learning Motivation}

In this section, students' online learning motivation at SHS-D schools will be classified into five categories, including very high, high, medium, low, and very low. This classification aims to determine the value of a group or sample. The results obtained from the classification of online learning motivation in SHS-A schools can be observed in Table 18.

Tabel 18 Results of Online Learning Motivation Classification in SHS-C Overall

\begin{tabular}{lcc}
\multicolumn{3}{c}{ Learning Motivation Classification } \\
\hline \multicolumn{1}{c}{ Classification } & Classification & Classification \\
\hline Very high & 1 & $3.45 \%$ \\
High & 10 & $34.48 \%$ \\
Medium & 15 & $51.72 \%$ \\
Low & 3 & $10.34 \%$ \\
Very low & 0 & 0 \\
\hline
\end{tabular}

Based on Table 18, the results of the online learning motivation classification in SHS-D as a whole with the largest number of subjects in the medium category as many as 15 students with a percentage value of $51.72 \%$.

\section{Classification of Student Learning Motivation by Gender}


The data obtained from the classification of students' learning motivation based on gender in SHS-D schools can be observed in Table 19.

Table 19 Results of Online Learning Motivation Classification in SHS-D Based on Gender

Learning Motivation Classification Based on Gender

\begin{tabular}{lcccc}
\hline \multirow{2}{*}{ Classification } & \multicolumn{2}{c}{ Number of students } & \multicolumn{2}{c}{ Percentage } \\
\cline { 2 - 5 } & Boys & Girls & Boys & Girls \\
\hline Very high & 1 & 0 & $11 \%$ & 0 \\
High & 3 & 7 & $33 \%$ & $35 \%$ \\
Medium & 4 & 11 & $44 \%$ & $55 \%$ \\
Low & 1 & 2 & $11 \%$ & $10 \%$ \\
Very low & 0 & 0 & 0 & 0 \\
\hline
\end{tabular}

The results obtained from the classification of learning motivation based on gender with the number of male students is nine students and the number of female students is 20 . Based on the data on motivation to learn in the SHS-D school, male students were in the medium category with a percentage value of $44 \%$, while female students were in the middle category with a percentage value of $55 \%$. There are differences in motivational categories between male students and female students in this case. This difference can be influenced by many internal and external factors from each student.

\section{Assessment Results on the Indicators of Students' Learning Motivation Aspects}

Exploring the level of student motivation in learning can be done in many ways. In this case, we used four aspect indicators: attention, relevance, confidence, and satisfaction. From the four indicators of learning motivation, it will be seen which aspect of motivation is more dominantly owned by students while following online learning. The data obtained from the assessment results on indicators of student motivation aspects can be observed in Table 20.

Table 20 Data Acquisition Aspects of Learning Motivation in General

Aspects of Learning Motivation in General

\begin{tabular}{lcc}
\hline \multicolumn{1}{c}{ Aspects } & Number of students & Percentage \\
\hline Attention & 613 & $66 \%$ \\
Relevance & 590 & $64 \%$ \\
Confidence & 629 & $68 \%$ \\
Satisfaction & 673 & $73 \%$ \\
\hline
\end{tabular}

Based on the results of the acquisition of indicators of learning motivation aspects in general in SHS-D schools in Table 20, the indicators of Satisfaction aspect have the largest score of 673 with a percentage of $73 \%$. This shows that students' motivation is quite good in terms of satisfaction in receiving learning. While on the aspect of Relevance with a score of 
590 with a percentage of $64 \%$. It is the lowest score, but there is still a moderate motivation classification.

\section{The Result of the Assessment of the Indicators of Students' Learning Motivation Based on Gender}

The data obtained from the assessment results on indicators of student motivation aspects based on gender in SHS-D schools can be observed in Table 21.

Table 21 Data Acquisition of Aspects of Learning Motivation Based on Gender Aspects of Learning Motivation Based on Gender

\begin{tabular}{lcccc}
\hline \multirow{2}{*}{ Aspects } & \multicolumn{2}{c}{ Number of students } & \multicolumn{2}{c}{ Percentage } \\
\cline { 2 - 5 } & Boys & Girls & Boys & Girls \\
\hline Attention & 167 & 446 & $24 \%$ & $25 \%$ \\
Relevance & 163 & 427 & $24 \%$ & $23 \%$ \\
Confidence & 167 & 462 & $24 \%$ & $25 \%$ \\
Satisfaction & 187 & 486 & $28 \%$ & $27 \%$ \\
\hline
\end{tabular}

Based on the results of data acquisition per-indicator aspects of learning motivation based on gender in SHS-D schools, the Satisfaction aspect has the highest percentage value, namely $28 \%$ for male students and $27 \%$ for female students. In this case, there is a $1 \%$ difference between female and male students in SHS-D.

\section{SHS-E}

Based on the results of the assessment of learning motivation at the SHS-E school during online learning, it is in the Medium category with an average score of 85 subjects from a total of 35 subjects, obtaining a subject percentage value of $66.21 \%$. These conditions indicate that students' learning motivation in SHS-E is included in the category of moderate learning motivation.

\section{Classification of Overall Student Learning Motivation}

In this section, students' online learning motivation at SHS-E schools will be classified into five categories, including very high, high, medium, low, and very low. This classification aims to determine the value of a group or sample. The results obtained from the classification of online learning motivation in SHS-E schools can be observed in Table 22.

Table 22 Overall Achievement of Online Learning Motivation Classification Results in SHS-E

\begin{tabular}{lcc}
\hline \multicolumn{3}{c}{ Learning Motivation Classification } \\
\hline \multicolumn{1}{c}{ Classification } & Number of students & Percentage \\
\hline Very high & 1 & $2.85 \%$ \\
High & 11 & $31.43 \%$ \\
Medium & 20 & $57.14 \%$ \\
Low & 2 & $5.71 \%$
\end{tabular}


Very low $\quad 1 \quad 2.86 \%$

Based on Table 22, the online learning motivation classification results at SHS-E as a whole, with the largest number of subjects in the medium category, were 20 students with a percentage value of $57.14 \%$.

\section{Classification of Student Learning Motivation by Gender}

The data obtained from the classification of students' learning motivation based on gender in SHS-E schools can be observed in Table 23.

Table 23 Results of Online Learning Motivation Classification in SHS-E Based on Gender Learning Motivation Classification Based on Gender

\begin{tabular}{lrrrr}
\hline \multirow{2}{*}{ Classification } & \multicolumn{2}{c}{ Number of students } & \multicolumn{2}{c}{ Percentage } \\
\cline { 2 - 5 } & Boys & Girls & \multicolumn{1}{c}{ Boys } & \multicolumn{1}{c}{ Girls } \\
\hline Very high & 1 & 0 & $8.33 \%$ & $0.00 \%$ \\
High & 2 & 9 & $16.67 \%$ & $39.13 \%$ \\
Medium & 8 & 12 & $66.67 \%$ & $52.17 \%$ \\
Low & 1 & 1 & $8.33 \%$ & $4.35 \%$ \\
Very low & 1 & 0 & 0 & $4.35 \%$ \\
\hline
\end{tabular}

The results obtained from the classification of learning motivation based on gender with the number of male students is 13 students and the number of female students is 22 . Based on the data on the motivation to study at the SHS-E school, male students were in the medium category with a percentage value of $67 \%$ while female students were in the middle category. In the medium category with a percentage value of $52.17 \%$. In this case, there are differences in motivational categories between male students and female students, this difference can be influenced by many factors, both internal and external from each student.

\section{Assessment Results on the Indicators of Students' Learning Motivation Aspects}

Exploring the level of student motivation in learning can be done in many ways. In this case, we used four aspect indicators: attention, relevance, confidence, and satisfaction. From the four indicators of learning motivation, it will be seen which aspect of motivation is more dominantly owned by students while following online learning. The data obtained from the assessment results on indicators of student motivation aspects can be observed in Table 24 .

Table 24 Data Acquisition Aspects of Learning Motivation in General

Aspects of Learning Motivation in General

\begin{tabular}{lcc}
\hline \multicolumn{1}{c}{ Aspects } & Number of students & Percentage \\
\hline Attention & 759 & $68 \%$ \\
Relevance & 698 & $62 \%$ \\
Confidence & 722 & $65 \%$ \\
Satisfaction & 787 & $70 \%$ \\
\hline
\end{tabular}


Based on the acquisition of indicators of learning motivation aspects in general in SHSE schools in Table 24, the indicators of Satisfaction aspect have the largest score of 787 with a percentage of $70 \%$. This shows that students' motivation is quite good in terms of satisfaction in receiving learning. While on the aspect of Relevance with a score of 698 with a percentage of $62 \%$. It is the lowest score, but there is still a classification of moderate motivation.

\section{The Result of the Assessment of the Indicators of Students' Learning Motivation Based on Gender}

The data obtained from the assessment results on indicators of student motivation aspects based on gender in SHS-E schools can be observed in Table 25.

Table 25 Data Acquisition of Aspects of Learning Motivation Based on Gender

Aspects of Learning Motivation Based on Gender

\begin{tabular}{lcccc}
\hline \multirow{2}{*}{ Aspects } & \multicolumn{2}{c}{ Number of students } & \multicolumn{2}{c}{ Percentage } \\
\cline { 2 - 5 } & Boys & Girls & Boys & Girls \\
\hline Attention & 260 & 499 & $25 \%$ & $26 \%$ \\
Relevance & 232 & 466 & $23 \%$ & $24 \%$ \\
Confidence & 261 & 461 & $25 \%$ & $24 \%$ \\
Satisfaction & 274 & 513 & $27 \%$ & $26 \%$ \\
\hline
\end{tabular}

Based on the results of data acquisition per-indicator aspects of learning motivation based on gender in SHS-E schools, the Satisfaction aspect has the highest percentage value, namely $27 \%$ for male students and $26 \%$ for female students in aspects of Satisfaction and Attention. In this case, there is a $1 \%$ difference between female and male students in SHS-E.

\section{SHS-F}

Based on the assessment of learning motivation at the SHS-F school during online learning, it is in the Medium category with an average score of 79 subjects out of 14 subjects. The percentage value of subjects is $61.66 \%$. This condition shows that students' learning motivation in SHS-F is included in the category of moderate learning motivation.

\section{Classification of Overall Student Learning Motivation}

In this section, students' online learning motivation at SHS-F schools will be classified into five categories, including very high, high, medium, low, and very low. This classification aims to determine the value of a group or sample. The results obtained from the classification of online learning motivation in SHS-F schools can be observed in Table 26.

Table 26 Overall Achievement of Online Learning Motivation Classification Results in SHSF

\begin{tabular}{lcc}
\hline \multicolumn{3}{c}{ Learning Motivation Classification } \\
\hline \multicolumn{1}{c}{ Classification } & Number of students & Percentage \\
\hline Very high & 0 & 0 \\
High & 2 & $14.28 \%$ \\
Medium & 10 & $71.43 \%$
\end{tabular}




\begin{tabular}{lll} 
Low & 1 & $7.14 \%$ \\
Very low & 1 & $7.14 \%$ \\
\hline
\end{tabular}

Based on Table 26, the Results of Online Learning Motivation Classification in SHS-F Overall with the largest number of subjects in the medium category as many as ten students with a percentage value of $71.43 \%$.

\section{Classification of Student Learning Motivation by Gender}

The data obtained from the classification of students' learning motivation based on gender in SHS-F schools can be observed in Table 27.

Table 27 Results of Online Learning Motivation Classification in SHS-F Based on Gender

\begin{tabular}{lrrrrr}
\hline \multicolumn{5}{c}{ Learning Motivation Classification Based on Gender } \\
\hline \multirow{2}{*}{ Classification } & \multicolumn{2}{c}{ Number of students } & \multicolumn{3}{c}{ Percentage } \\
\cline { 2 - 5 } & Boys & Girls & Boys & Girls \\
\hline Very high & 0 & 0 & 0 & 0 \\
High & 1 & 1 & $25 \%$ & $11.11 \%$ \\
Medium & 2 & 7 & $50 \%$ & $77.78 \%$ \\
Low & 0 & 1 & 0 & $11.11 \%$ \\
Very low & 1 & 0 & $25 \%$ & 0 \\
\hline
\end{tabular}

The results obtained from the classification of learning motivation based on gender with the number of male students is four students and the number of female students is nine. Based on the data on Motivation to learn at the SHS-F school, male students are in the medium category with a percentage value of $50 \%$, while female students are in the middle category. In the medium category with a percentage value of $77.78 \%$. In this case, there are differences in motivational categories between male students and female students. This difference can be influenced by many internal and external factors from each student.

\section{Assessment Results on the Indicators of Students' Learning Motivation Aspects}

Exploring the level of student motivation in learning can be done in many ways. In this case, we used four aspect indicators: attention, relevance, confidence, and satisfaction. From the four indicators of learning motivation, it will be seen which aspect of motivation is more dominantly owned by students while following online learning. The data obtained from the assessment results on indicators of student motivation aspects can be observed in Table 28.

Table 28 Data Acquisition Aspects of Learning Motivation in General

Aspects of Learning Motivation in General

\begin{tabular}{lcc}
\hline \multicolumn{1}{c}{ Aspects } & Number of students & Percentage \\
\hline Attention & 268 & $60 \%$ \\
Relevance & 260 & $58 \%$ \\
Confidence & 282 & $63 \%$
\end{tabular}


Based on the results of the acquisition of indicators of learning motivation aspects in general in SHS-F schools in Table 28, the indicators of Satisfaction aspect have the largest score of 295 with a percentage of $66 \%$. This shows that students' motivation is quite good in terms of satisfaction in receiving learning. While the Relevance aspect with a score of 260 with a percentage of $58 \%$ is at the lowest score, but is still classified as moderate motivation.

\section{The Result of the Assessment of the Indicators of Students' Learning Motivation Based on Gender}

The data obtained from the assessment results on indicators of student motivation aspects based on gender in SHS-F schools can be observed in Table 29.

Table 29 Data Acquisition of Aspects of Learning Motivation Based on Gender

Aspects of Learning Motivation Based on Gender

\begin{tabular}{lcccc}
\hline \multirow{2}{*}{ Aspects } & \multicolumn{2}{c}{ Number of students } & \multicolumn{2}{c}{ Percentage } \\
\cline { 2 - 5 } & Boys & Girls & Boys & Girls \\
\hline Attention & 73 & 195 & $24 \%$ & $26 \%$ \\
Relevance & 73 & 187 & $24 \%$ & $24 \%$ \\
Confidence & 81 & 201 & $27 \%$ & $24 \%$ \\
Satisfaction & 78 & 217 & $26 \%$ & $26 \%$ \\
\hline
\end{tabular}

Based on the results of data acquisition per-indicator aspects of learning motivation based on gender in SHS-F schools, the Satisfaction aspect has the highest percentage value, namely $26 \%$ for male students and $26 \%$ for female students. In this case, there is a $1 \%$ difference between female and male students in SHS-F.

\section{SHS-G}

Based on the results of the assessment of learning motivation at the SHS-G school during online learning, it is in the Medium category with an average score of 87 subjects out of a total of 23 subjects, obtaining a subject percentage value of $67.66 \%$. This condition shows that students' learning motivation in SHS-G is included in the category of moderate learning motivation.

\section{Classification of Overall Student Learning Motivation}

In this section, students' online learning motivation at SHS-G schools will be classified into five categories, including very high, high, medium, low, and very low. This classification aims to determine the value of a group or sample. The results obtained from the classification of online learning motivation in SHS-G schools can be observed in Table 30. 
Table 30 Overall Achievement of Online Learning Motivation Classification Results in SHS$\mathrm{G}$

\begin{tabular}{lcc}
\hline \multicolumn{2}{c}{ Learning Motivation Classification } \\
\hline \multicolumn{1}{c}{ Classification } & Number of students & Percentage \\
\hline Very high & 0 & 0 \\
High & 11 & $47.83 \%$ \\
Medium & 11 & $47.83 \%$ \\
Low & 1 & $4.35 \%$ \\
Very low & 0 & 0 \\
\hline
\end{tabular}

Based on Table 30, the Results of Online Learning Motivation Classification at SHS-G Overall with the largest number of subjects in the high category and the medium category as many as 11 students with a percentage value of $47.83 \%$.

\section{Classification of Student Learning Motivation by Gender}

The data obtained from the classification of students' learning motivation based on gender in SHS-G schools can be observed. In this section, students' online learning motivation at SHSG schools will be classified into five categories, including very high, high, medium, low, and very low. This classification aims to determine the value of a group or sample. Can be observed in Table 31.

Table 31 Results of Online Learning Motivation Classification in SHS-G Based on Gender Aspects of Learning Motivation Based on Gender

\begin{tabular}{lcccc}
\hline \multirow{2}{*}{ Aspects } & \multicolumn{2}{c}{ Number of students } & \multicolumn{2}{c}{ Percentage } \\
\cline { 2 - 5 } & Boys & Girls & Boys & Girls \\
\hline Very high & 0 & 0 & 0 & 0 \\
High & 4 & 7 & $40 \%$ & $53.85 \%$ \\
Medium & 6 & 5 & $60 \%$ & $38.46 \%$ \\
Low & 0 & 1 & 0 & $7.70 \%$ \\
Very low & 0 & 0 & 0 & 0 \\
\hline
\end{tabular}

The results of the classification of learning motivation based on gender with the number of male students is ten students and the number of female students is 13 . Based on the data on the motivation to study at the SHS-G school, male students were in the medium category with a percentage value of $60 \%$ while female students were in the middle category. in the high category with a percentage value of $53.85 \%$. In this case, there are differences in motivational categories between male students and female students, this difference can be influenced by many factors, both internal and external from each student. 
Exploring the level of student motivation in learning can be done in many ways. In this case, we used four aspect indicators: attention, relevance, confidence, and satisfaction. From the four indicators of learning motivation, it will be seen which aspect of motivation is more dominantly owned by students while following online learning. The data obtained from the assessment results on indicators of student motivation aspects can be observed in Table 32 .

Table 32 Data Acquisition Aspects of Learning Motivation in General

Aspects of Learning Motivation in General

\begin{tabular}{lcc}
\hline \multicolumn{1}{c}{ Aspects } & Number of students & Percentage \\
\hline Attention & 510 & $69 \%$ \\
Relevance & 465 & $63 \%$ \\
Confidence & 524 & $71 \%$ \\
Satisfaction & 555 & $75 \%$ \\
\hline
\end{tabular}

Based on the results of the acquisition of indicators of learning motivation aspects in general in SHS-G schools in Table 32, the indicators of Satisfaction aspect have the largest score of 555 with a percentage of $75 \%$. This shows that students' motivation is quite good in terms of satisfaction in receiving learning. While the Relevance aspect with a score of 465 with a percentage of $63 \%$ is at the lowest score. It is still in the classification of moderate motivation.

\section{The Result of the Assessment of the Indicators of Students' Learning Motivation Based on Gender}

The data obtained from the assessment results on indicators of student motivation aspects based on gender in SHS-G schools can be observed in Table 33.

Table 33 Data Acquisition of Aspects of Learning Motivation Based on Gender

Aspects of Learning Motivation Based on Gender

\begin{tabular}{lcccc}
\hline \multirow{2}{*}{ Aspects } & \multicolumn{2}{c}{ Number of students } & \multicolumn{2}{c}{ Percentage } \\
\cline { 2 - 5 } & Boys & Girls & Boys & Girls \\
\hline Attention & 216 & 294 & $24 \%$ & $25 \%$ \\
Relevance & 206 & 259 & $23 \%$ & $22 \%$ \\
Confidence & 230 & 294 & $26 \%$ & $25 \%$ \\
Satisfaction & 240 & 313 & $27 \%$ & $28 \%$ \\
\hline
\end{tabular}

Based on the results of data acquisition per-indicator aspects of learning motivation based on gender in SHS-G schools, the Satisfaction aspect has the highest percentage value, namely $27 \%$ for male students and $28 \%$ for female students. In this case, there is a $1 \%$ difference between female and male students in SHS-G.

\section{SHS-H}

Based on the results of the assessment of learning motivation in SHS-H schools during online learning, it is in the Medium category with an average subject score of 90 out of a total 
of 35 subjects, obtaining a subject percentage value of $70.54 \%$. These conditions indicate that students' learning motivation at SHS-H is included in the category of High learning motivation.

\section{Classification of Overall Student Learning Motivation}

In this section, students' online learning motivation at SHS-H schools will be classified into five categories, including very high, high, medium, low, and very low. This classification aims to determine the value of a group or sample. The results obtained from the classification of online learning motivation in SHS-H schools can be observed in Table 34.

Table 34 Overall Achievement of Online Learning Motivation Classification Results in SHS$\mathrm{H}$

Learning Motivation Classification

\begin{tabular}{lcc}
\hline \multicolumn{1}{c}{ Classification } & Number of students & Percentage \\
\hline Very high & 3 & $8.57 \%$ \\
High & 19 & $54.28 \%$ \\
Medium & 11 & $31.43 \%$ \\
Low & 2 & $5.71 \%$ \\
Very low & 0 & $0 \%$ \\
\hline
\end{tabular}

Based on Table 34, the results of the online learning motivation classification at SHS-H as a whole with the largest number of subjects in the high category as many as 19 students with a percentage value of $54.28 \%$.

\section{Classification of Student Learning Motivation by Gender}

The data obtained from the classification of students' learning motivation based on gender in SHS-H schools can be observed. In this section, students' online learning motivation at SHSHschools will be classified into five categories, including very high, high, medium, low, and very low. This classification aims to determine the value of a group or sample. Can be observed in Table 35.

Table 31 Results of Online Learning Motivation Classification in SHS-H Based on Gender

Learning Motivation Classification Based on Gender

\begin{tabular}{lllll}
\hline \multirow{2}{*}{ Classification } & \multicolumn{2}{l}{ Number of students } & \multicolumn{2}{l}{ Percentage } \\
\cline { 2 - 5 } & Boys & Girls & Boys & Girls \\
\hline Very high & 0 & 3 & 0 & $12 \%$ \\
High & 7 & 12 & $70 \%$ & $48 \%$ \\
Medium & 3 & 8 & $30 \%$ & $32 \%$ \\
Low & 0 & 2 & 0 & $8 \%$ \\
Very low & 0 & 0 & 0 & 0 \\
\hline
\end{tabular}


Based on Table 35, the results obtained from the Online Learning Motivation Classification at SHS-H Overall with the largest number of subjects in the high category with a total of 10 male students with a percentage value of $70 \%$, while female students were in the high classification with a total of 25 students with a percentage value of $48 \%$.

\section{Assessment Results on the Indicators of Students' Learning Motivation Aspects}

Exploring the level of student motivation in learning can be done in many ways. In this case, we used four aspect indicators: attention, relevance, confidence, and satisfaction. From the four indicators of learning motivation, it will be seen which aspect of motivation is more dominantly owned by students while following online learning. The data obtained from the assessment results on indicators of student motivation aspects can be observed in Table 35 .

Table 35 Data Acquisition Aspects of Learning Motivation in General

\begin{tabular}{lcc}
\multicolumn{3}{c}{ Learning Motivation Aspect } \\
\hline \multicolumn{1}{c}{ Aspect } & Number of students & Percentage \\
\hline Attention & 775 & $69 \%$ \\
Relevance & 741 & $66 \%$ \\
Confidence & 808 & $72 \%$ \\
Satisfaction & 836 & $74 \%$ \\
\hline
\end{tabular}

Based on the results of the acquisition of indicators of learning motivation aspects in general in SHS-H schools in Table 35 the indicators of Satisfaction aspect have the largest score of 836 with a percentage of $74 \%$. This shows that students' motivation is quite good in terms of satisfaction in receiving learning. While the Relevance aspect with a score of 741 with a percentage of $66 \%$ is at the lowest score, but is still classified as moderate motivation.

\section{The Result of the Assessment of the Indicators of Students' Learning Motivation Based on Gender}

The data obtained from the assessment results on indicators of student motivation aspects based on gender in SHS-H schools can be observed in Table 36.

Table 13 Data Acquisition of Aspects of Learning Motivation Based on Gender Aspects of Learning Motivation Based on Gender

\begin{tabular}{lcccc}
\hline \multirow{2}{*}{ Aspects } & \multicolumn{2}{c}{ Number of students } & \multicolumn{2}{c}{ Percentage } \\
\cline { 2 - 5 } & Boys & Girls & Boys & Girls \\
\hline Attention & 249 & 529 & $24 \%$ & $25 \%$ \\
Relevance & 244 & 497 & $24 \%$ & $23 \%$ \\
Confidence & 260 & 548 & $26 \%$ & $25 \%$ \\
Satisfaction & 261 & 575 & $26 \%$ & $27 \%$ \\
\hline
\end{tabular}

Based on the results of data acquisition per-indicator aspects of learning motivation based on gender in SHS-H schools, the Satisfaction aspect has the highest percentage value, namely 
$26 \%$ for male students and $27 \%$ for female students. In this case, there is a $1 \%$ difference between female and male students in SHS-H.

The results of this study focus on discussing how the level of student motivation in general and based on gender-based on ARCS theory, then how the percentage of contributions from each aspect of ARCS in general and based on gender to the level of student motivation in high school students in Balikpapan after participating in E-Learning Physics Learning. This research was conducted in several public schools in Balikpapan, with as many as 275 students. The responses from all respondents were then tabulated and the scores were calculated to determine the level of student learning motivation based on e-learning in general and by gender, as well as to determine the percentage value of the ARCS aspect. The acquisition of learning motivation classification data in general can be observed in Figure 1

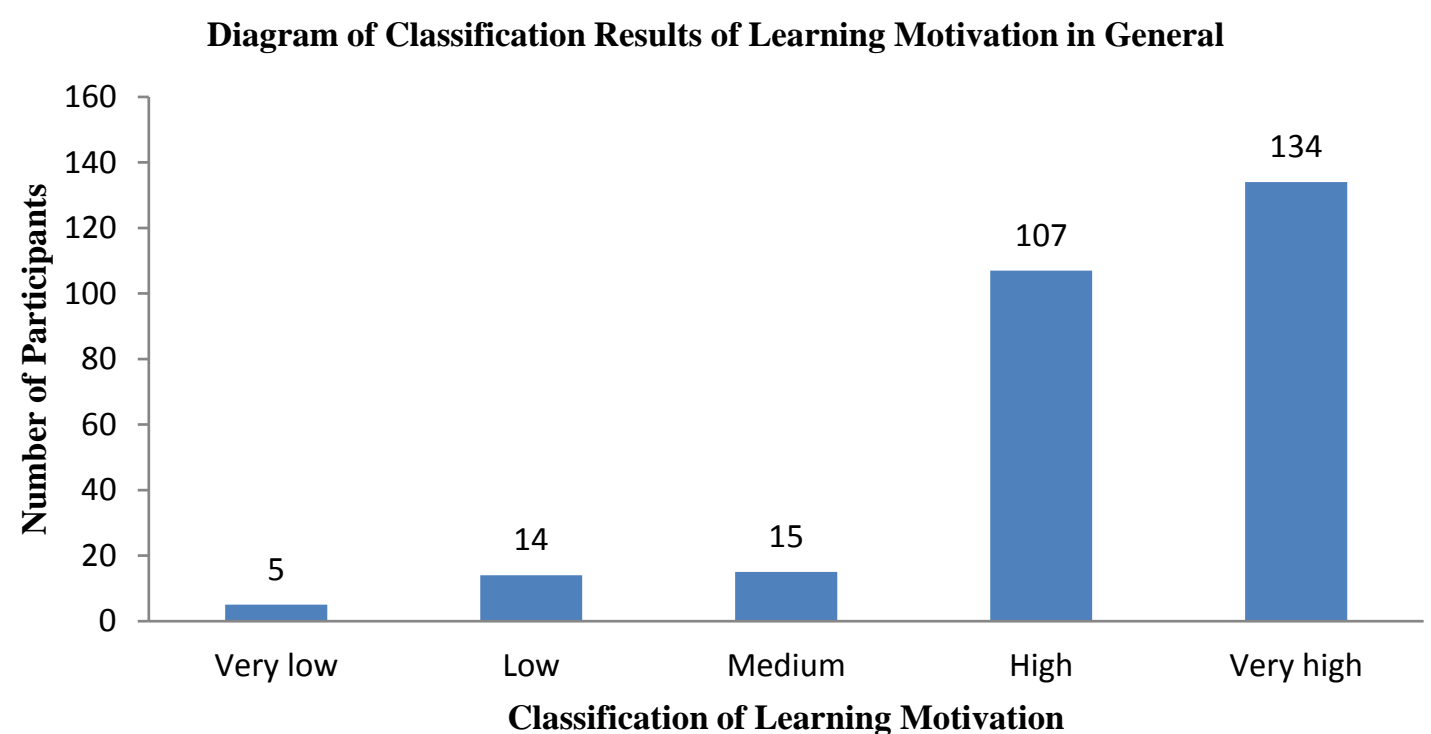

Figure 1 Results of Classification of Learning Motivation in General

Obtaining data on the classification of learning motivation by gender. This difference classification was made to determine the difference in the level of learning motivation between male and female students. Classification of learning motivation based on gender can be observed in Figure 2. 


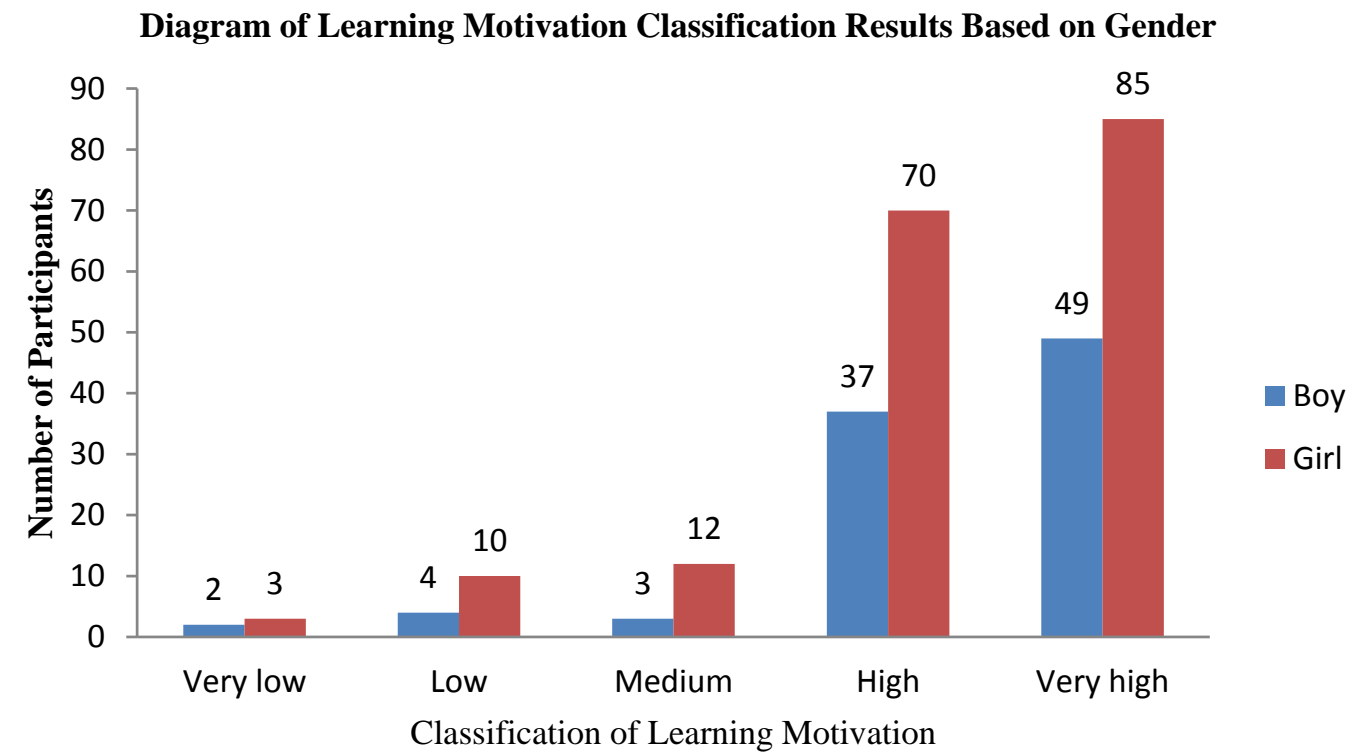

Figure 2 Results of Classification of Learning Motivation Based on Gender

Physics learning motivation is categorized into motivational groups, including very high, high, medium, low, and very low, which is then determined by the percentage to determine the level of student motivation in general in high school in Balikpapan, Indonesia. The data acquisition of student motivation analysis in general can be observed in Figure 3.

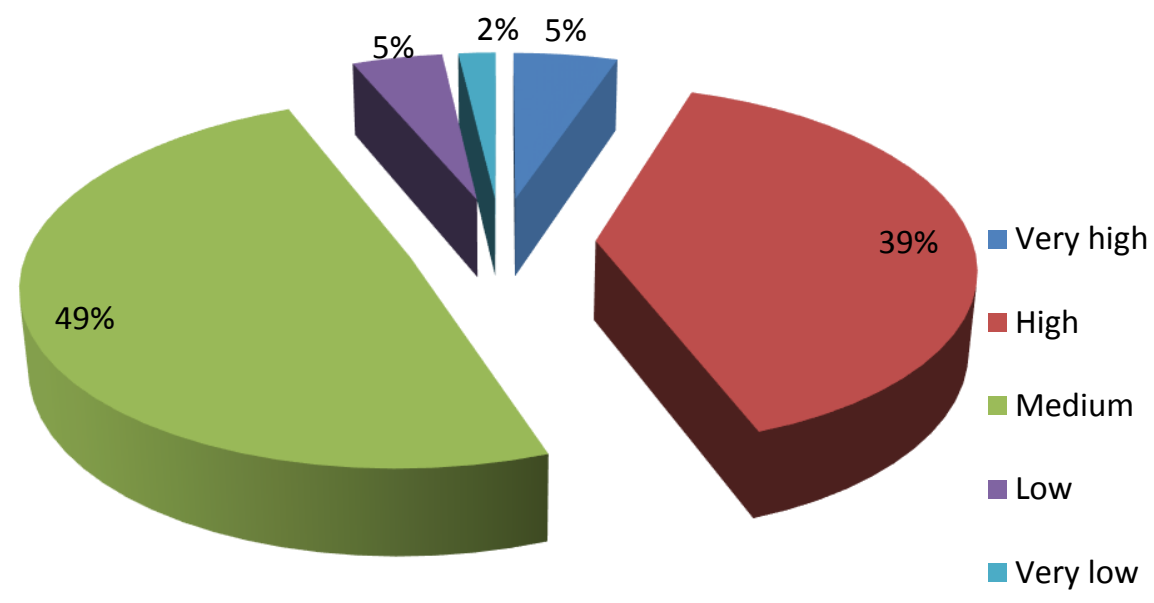

Figure 3. Percentage (\%) Learning Motivation in General

The following can be observed the percentage of learning motivation based on gender in Table 37 in order to determine the value of the percentage of motivation of male students and female students in participating in physics learning activities by E-Learning. 
Table 37 Percentage (\%) Learning Motivation Based on Gender

Percentage (\%) Learning Motivation Based on Gender

\begin{tabular}{lcc}
\hline \multicolumn{1}{c}{ Clasification } & Boys & Girls \\
\hline Very high & $28.57 \%$ & $71.43 \%$ \\
High & $34.58 \%$ & $65.42 \%$ \\
Medium & $36.57 \%$ & $63.43 \%$ \\
Low & $20.00 \%$ & $80.00 \%$ \\
Very low & $40.00 \%$ & $60.00 \%$ \\
\hline
\end{tabular}

The following is the acquisition of the percentage value of each ARCS aspect in general on the learning motivation of students based on E-Learning in Public Senior High Schools throughout Balikpapan, can be observed in Figure 4.

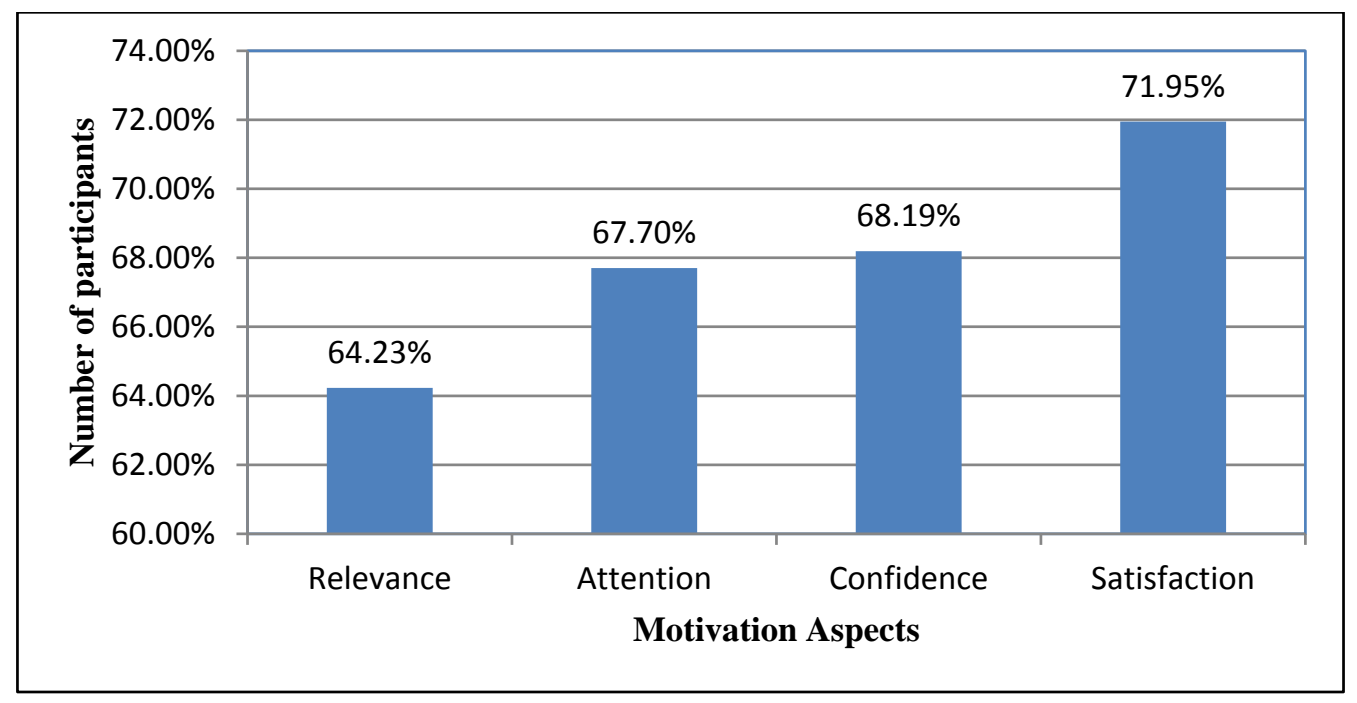

Figure 4 Percentage Value (\%) From ARCS Aspects in General

The following is the acquisition of the percentage value of each ARCS aspect based on the gender on students' learning motivation based on E-Learning in Public Senior High Schools throughout Balikpapan, which can be observed in Table 38.

Table 38 Percentage $(\%)$ of ARCS Aspects Based on Gender

\begin{tabular}{lcc}
\hline \multicolumn{3}{c}{ Percentage Based on ARCS Aspects } \\
\hline \multicolumn{1}{c}{ Aspects } & Boys & Girls \\
\hline Attention & $67.53 \%$ & $67.80 \%$ \\
Relevance & $65.07 \%$ & $63.78 \%$ \\
Confidence & $69.41 \%$ & $67.55 \%$ \\
Satisfaction & $72.37 \%$ & $71.74 \%$ \\
\hline
\end{tabular}

Learning motivation was measured using a questionnaire and an interview sheet based on the indicators of the ARCS aspect. E-Learning-based physics learning motivation questionnaires were given to students after participating in online physics lessons for the past few months to determine the level of student motivation in learning. This is the background for 
researchers to conduct research on the level of student motivation based on the ARCS theory based on E-Learning in public high schools, especially in Balikpapan.

The results showed that the motivation to learn physics based on the ARCS aspect based on e-learning in Public Senior High Schools throughout Balikpapan was generally in the category of moderate learning motivation with the largest percentage of $49.00 \%$. Several studies strengthen the results of this study sari et al (2018) which measure the level of motivation to learn physics using the ARCS aspect. Where the results are in the medium category with the respective percentages of $58.89 \%$ and $34.00 \%$. The motivation category of male students is in the medium category, in this case male students are quite interested in e-learning learning activities as well as female students. However, in the results of this analysis, learning motivation in the medium category based on gender is dominated by male students by $51.58 \%$, while female students by $47.22 \%$. Anita (2015) argues that there are differences in values (presentations) that can be seen from students' amount of motivation. This is influenced by several aspects of life experienced by students. Based on the results of questionnaire analysis and interviews by several students, the driving force possessed by students is the form of the value of responsibility where students realize this education. It is students' responsibility so that students have a desire to pay attention to learning and follow the learning process with a sense of responsibility.

This E-Learning-based student motivation questionnaire also analyzes the percentage based on the contribution of each aspect of Attention, Relevance, Confidence and Satisfaction. Based on the data analysis, it can be seen that the aspects of learning motivation measured using ARCS indicators have different percentage results in their influence on students' learning motivation based on E-Learning. This E-Learning-based student motivation questionnaire also analyzes the percentage based on the contribution of each aspect of Attention, Relevance, Confidence and Satisfaction. Based on the data analysis, it can be seen that the aspects of learning motivation measured using ARCS indicators have different percentage results in their influence on students' learning motivation based on E-Learning. The measured ARCS indicators include Attention having a percentage of $67.70 \%$ of which $67.53 \%$ are male and $67.80 \%$ female, while the Relevance aspect has a percentage of $64.23 \%$ of which $65.07 \%$ are male and $63.78 \%$ female, while the Confidence aspect has a percentage of $68.19 \%$ of the $69.41 \%$ male and $67.55 \%$ female, and for the aspect of Satisfaction has a percentage of $71.95 \%$ of them $72.37 \%$ male and $71.74 \%$ female. The Satisfaction aspect places the highest percentage in growing students' learning motivation based on E-Learning. 
International Journal of STEM Education for Sustainability, Vol 2, No.1, 2022, pp. 105-132 e-ISSN 2798-5091. DOI. 10.53889/ijses.v2i1.15

\section{CONCLUSION}

Based on the results of the research that has been carried out, the results show that the level of student motivation, in general, is in the moderate category with a percentage of $49 \%$, while the percentage of motivation based on gender is $37 \%$ for male students and the percentage for female students is $63 \%$. The percentage value for each ARCS aspects, in general, are $67.70 \%$ for Attention, 64.23\% for Relevance, 68.19\% for Confidence, and 71.95\% for Satisfaction, while the percentage value based on gender is $67.53 \%$ for male Attention, $67.80 \%$ for female; Male relevance $65.07 \%$, female $63.78 \%$; Confidence male $69.41 \%$, female $67.55 \%$; and $72.37 \%$ male satisfaction, $71.74 \%$ female.

\section{SUGGESTIONS}

The researcher suggests that future research related to the analysis of student motivation based on the ARCS model in physics learning based on E-Learning. Future research should simultaneously apply the ARCS learning model to explore student motivation in learning, especially in learning physics.

\section{ACKNOWLEDGEMENT}

The researcher expresses his deepest gratitude to the board of teachers at high schools in Balikpapan, Indonesia for collaborating and allowing the continuation of this research. Thanks to the participants for taking the time.

\section{REFERENCES}

Aji, R. H. S. (2020). Dampak COVID-19 pada pendidikan di Indonesia: Sekolah, keterampilan, dan proses pembelajaran. Jurnal Sosial \& Budaya Syar-i, 7(5), 395-402.

Anita, I. W. A. W. (2015). Pengaruh motivasi belajar ditinjau dari jenis kelamin terhadap kemampuan berpikir kritis matematis. Jurnal Ilmiah P2M STKIP Siliwangi, 2(2), 246251.

Dewi, W. A. F. (2020). Dampak Covid-19 terhadap implementasi pembelajaran daring di Sekolah Dasar. Edukatif: Jurnal Ilmu Pendidikan, 2(1), 55-61.

Fitriah, L. (2018). Motivasi belajar mahasiswa Prodi Tadris Fisika UIN Antasari Banjarmasin pada perkuliahan Fisika Dasar 1 dalam setting strategi motivasi ARCS. Berkala Ilmiah Pendidikan Fisika, 6(2), 157.

Herniati, R., Sulistri, E., \& Rosdianto, H. (2017). Penerapan Model Predict Observe Explain Dengan Pendekatan Learning by Doing Untuk Meningkatkan Hasil Belajar Siswa. Jurnal Fisika Flux: Jurnal Ilmiah Fisika FMIPA Universitas Lambung Mangkurat, 14(2), 120124.

Jamil, M. M. (2019). Optimalisasi Model ARCS Dalam Pembelajaran Saintifik Untuk Meningkatkan Motivasi Belajar Peserta Didik Pada Peminatan Mata Pelajaran Geografi Di Kelas Matematika Ilmu Alam. IJIS Edu: Indonesian Journal of Integrated Science Education, 1(1), 7-24. 
Keller, J. M. (1983). Motivational design of instruction. In C. M. Reigeluth (Ed.), Instructional design theories and models: An overview of their current status. Hillsdale, NJ: Erlbaum.

Nasution, S. H. (2018). Pentingnya literasi teknologi bagi mahasiswa calon guru matematika. Jurnal Kajian Pembelajaran Matematika, 2(1), 14-18.

Nur, A. S., \& Palobo, M. (2018). Profil kemampuan pemecahan masalah matematika siswa ditinjau dari perbedaan gaya kognitif dan gender. Kreano, Jurnal Matematika KreatifInovatif, 9(2), 139-148.

Sari, N., Sunarno, W., \& Sarwanto, S. (2018). Analisis motivasi belajar siswa dalam pembelajaran fisika sekolah menengah atas. Jurnal Pendidikan dan Kebudayaan, 3(1), 260934.

Suprijono, A. (2010). Cooperative Learning Teori Dan Aplikasi. Pustaka Pelajar: Yogyakarta

Ulfah, Y., An'nur, S., \& Mahardika, A. I. (2015). Hubungan antara minat dan motivasi dengan hasil belajar fisika siswa kelas x sman 10 banjarmasin. Berkala Ilmiah Pendidikan Fisika, 3(2), 146-153. 